\title{
Protein Regulator of Cytokinesis 1
}

National Cancer Institute

\section{Source}

National Cancer Institute. Protein Regulator of Cytokinesis 1. NCI Thesaurus. Code C118351.

Protein regulator of cytokinesis 1 ( $620 \mathrm{aa}, \sim 72 \mathrm{kDa}$ ) is encoded by the human PRC1 gene. This protein is involved in both mitotic spindle crosslinks and cytokinesis. 